Niepełnosprawność. Dyskursy pedagogiki specjalnej

\title{
Danuta Wolska
}

Uniwersytet Pedagogiczny, Kraków

\section{Poziom umiejętności życiowych osób z głębszą niepełnosprawnością intelektualną - beneficjentów zatrudnienia wspomaganego}

\author{
The level of life competence of people with moderate, severe \\ and profound intellectual disabilities - beneficiaries of supported \\ employment
}

Paid employment, adapted to the capabilities of people with more severe intellectual disabilities, can not only contribute to their physical fitness but also shape their motor habits and improve their manual dexterity. The results of the studies conducted indicate that in order for a person with more severe disability to be able to cope well with the work they must in the course of life master life skills in the scope of self-care, making decisions, building their own system of values, coping with stress, earning a living as well as interpersonal skills related to communication.

Słowa kluczowe: osoba z niepełnosprawnością intelektualną, praca, umiejętności życiowe

Keywords: a person with intellectual disability, work, life skills

\section{Wprowadzenie}

Dzięki realizacji projektów zatrudnienia wspomaganego, osoby z głębszą niepełnosprawnością intelektualną, od kilku lat mają możliwość przygotowania się do podjęcia pracy oraz utrzymania jej przez czas dłuższy niż okres trwania projektu. Koncepcja zatrudnienia wspomaganego polega na zatrudnianiu osoby niepełnosprawnej przez pracodawcę po ustaleniu warunków i zasad pracy z trenerem, który towarzyszy nowemu pracownikowi przez okres około 6 miesięcy i udziela szeroko rozumianej pomocy. Pomoc ta może obejmować ocenę możliwości zawodowych, znalezienie miejsca pracy, przygotowanie dokumentów, przeszkolenie do wykonywania zawodu, wsparcie w budowaniu relacji ze współ- pracownikami. Trener pracy z upływem czasu zmniejsza udzielaną pomoc, tak, aby pra- 
cownik niepełnosprawny mógł się usamodzielnić (Majewski 2011, s. 69). Przeprowadzone badania własne (Wolska 2015) wskazują, że jednym z predykatorów do podjęcia aktywności zawodowej przez osoby z głębszą niepełnosprawnością intelektualną są umiejętności życiowe, które opanowali oni w biegu całego życia. Badaniami objęto 200 beneficjentów projektów zatrudnienia wspomaganego realizowanych przez ChSON "Ognisko" w Krakowie w latach 2010-2015. Pierwszą grupę badawczą stanowiły osoby z głębszą niepełnosprawnością intelektualną, które po zakończeniu udziału w projekcie podjęły pracę i ją kontynuowały. Grupa druga to beneficjenci, którzy nie podjęli zatrudnienia, chociaż pomyślnie zakończyli projekt. Dzięki wykorzystaniu modelowania równań strukturalnych dokonałam analizy struktury oraz siły liniowych zależności pomiędzy umiejętnościami życiowymi, które najsilniej wpływały na zależności pomiędzy poszczególnymi zmiennymi. Po opuszczeniu mało znaczących połączeń powstały modele 3-wariancyjne. Szczegółową ich analizę przedstawiono w końcowej części artykułu.

\section{Umiejętności życiowe kluczem do autonomii osób z głębszą niepełnosprawnością intelektualną}

Osoby z głębszą niepełnosprawnością intelektualną, aby odnaleźć swoje miejsce $\mathrm{w}$ społeczeństwie, rodzinie, $\mathrm{w}$ pracy, powinny w biegu całego życia opanować umiejętności, które pozwolą im sprostać zadaniom i wymaganiom, jakie stawia codzienne życie. Pod pojęciem umiejętności A. Giermakowska (2007) rozumie zdolność, zdatność do wykonywania różnorakich czynności praktycznych i sytuacyjnych. Określane są jako kompetencje, sprawności, biegłość, wprawa, skuteczność, zręczność. Są też złożoną umiejętnością, która warunkuje efektywność radzenia sobie w określonego typu sytuacjach społecznych, osiaganych przez daną osobę niepełnosprawną podczas treningu społecznego $\mathrm{w}$ szkole lub centrach aktywności dla dorosłych. Są dyspozycją, którą człowiek wykorzystuje podejmując zadania życiowe $\mathrm{w}$ wymiarze prywatnym oraz społecznym, do adekwatnego reagowania na różne sytuacje społeczne i odpowiada na stawiane przez nie wyzwania (Błeszyński 2013, s. 37). To czynności uwarunkowane doświadczeniem gatunkowym, aktywizowane przez wpływy środowiska, odnoszące się do relacji człowiek - otoczenie i w dużym znaczeniu powiązane z efektywnością działania. Kiedy człowiek jest gotowy do świadomego działania opartego na odpowiedniej wiedzy, którą potrafi dostosować do zmieniających się warunków, wtedy można powiedzieć, że posiada odpowiedni zasób umiejętności życiowych (Wolska 2015). Ta gotowość czy możliwość celowego działania z wyborem, która przez zastosowanie najbardziej odpowiednich zasobów czy warunków gwaran- 
tuje właściwe rezultaty owego działania, może zostać nazwana umiejętnością. Umiejętności życiowe są bardzo ważne, gdyż prowadzą do pozytywnego zachowania przystosowawczego, umożliwiają radzenie sobie z zadaniami i wyzwaniami życia codziennego. Analiza literatury (Woynarowska 2002, 2007; Maksymowicz 2009) pozwala na przedstawienie umiejętności życiowych ważnych w życiu dorosłego człowieka. Przeprowadzone badania własne w latach 2010-2015 pozwolity wyodrębnić te umiejętności życiowe, które są priorytetowe dla osób z głębszą niepełnosprawnością intelektualną i znacząco wpływają na podejmowane przez nie role $\mathrm{w}$ dorosłym życiu.

Jedną z najważniejszych umiejętności jest rozwój samoobsługi, gdyż na każdym etapie życia osoby z głębszą niepełnosprawnością intelektualną wpływa on na jej autonomię i adekwatną samoocenę. Jeśli osoba ma świadomość własnych umiejętności samoobsługowych oraz ograniczeń wynikających z niemożności opanowania niektórych z nich to jej samoocena jest adekwatna oraz wzrasta jakość jej życia. Umiejętności zwiq̨zane z samoobstugą trzeba rozwijać w biegu całego życia w szkole, rodzinie, w środowisku bliższym i dalszym. Proste umiejętności, takie jak: włożenie naczyń do zmywarki, umycie okien, dbanie o higienę osobistą, witanie się z ludźmi, odbieranie telefonu i zanotowanie wiadomości, oznaczają opanowanie umiejętności, dzięki którym osoba z niepełnosprawnością intelektualną stanie się akceptowana i szanowana w otoczeniu społecznym. Uczestnictwo w obowiązkach domowych, komentowanie wspólnie wykonywanych zadań, uczenie się dobrych manier i ćwiczenie koncentracji uwagi - wszystko to jest częścią procesu stawania się społecznie odpowiedzialną osobą, która jest gotowa do podjęcia pracy - i co najważniejsze - do jej utrzymania.

Rozwój umiejętności interpersonalnych zwiazanych z komunikowaniem się osób z niepełnosprawnością intelektualną to kolejne zadanie dla rodziców, nauczycieli i terapeutów, bowiem najszybciej uczą się one komunikować dzięki pośrednictwu i wsparciu innych. U osób z niepełnosprawnością intelektualną umiejętności interpersonalne związane $\mathrm{z}$ komunikowaniem są często zaburzone z powodu nieprawidłowej artykulacji, małej koncentracji uwagi, słabej konsolidacji śladów pamięciowych czy zaburzeń słuchu. Ubogi zasób słownictwa pozwala im porozumiewać się z najbliższym otoczeniem jedynie $\mathrm{w}$ zakresie podstawowych spraw życia codziennego, w dużym stopniu utrudnia prawidłowe rozumienie słów i zdań formułowanych przez innych. Dlatego od najmłodszych lat rodzina powinna zadbać o możliwość udzielenia dziecku profesjonalnego wsparcia logopedycznego, by zmniejszyć zaburzenia mowy i wypracować prawidłowe sposoby komunikowania się z otoczeniem. Należy też zadbać o zwiększenie zasobu słownictwa dziecka, zwracać uwagę na rozwój mowy i sposób formułowania przekazu oraz kształtowanie umiejętności odbioru adekwatnego do przekazanych informacji. W. Pilecka (2012) zwraca też uwagę na konieczność rozwijania 
właściwych form komunikacji przekazującej - zarówno ekspresji własnych stanów uczuciowych i przeżyć za pomocą sygnałów sensoryczno-motorycznych, jak i właściwej ich interpretacji przez odbiorcę. Ma to decydujące znaczenie podczas podejmowania aktywności zawodowej przez osoby z niepełnosprawnością intelektualną, w komunikacji z pracodawcą oraz współpracownikami i klientami.

Umiejętności podejmowania decyzji i odpowiedzialność to zadanie, które w pracy z osobami z głębszą niepełnosprawnością intelektualną podejmowane jest od niedawna. A przecież jedną z podstaw samostanowienia o sobie, czyli decydowanie o indywidualnych wyborach życiowych jest podejmowanie różnego rodzaju aktywności życiowych oraz możliwość realizacji własnych potrzeb. Osobę zdolną do samodzielnego podejmowania decyzji charakteryzuje umiejętność przejawiania inicjatyw w różnych sytuacjach, świadomość rozwijania własnych możliwości, umiejętność dokonywania wyborów i stawiania sobie celów oraz rozwiązywania problemów, umiejętność niezależnego myślenia, asertywność, umiejętność obrony samego siebie i samowiedza (Pilecka 2012). Samodzielne podejmowanie decyzji związane jest $\mathrm{z}$ odpowiedzialnością. Prowadzone przez autorkę badania własne (Wolska 2015) wskazują, że rodzice i terapeuci osób z niepełnosprawnością intelektualną kładą nieduży nacisk na rozwój tych umiejętności życiowych. $Z$ jednej strony jest $w$ nich mała wiara $w$ to, że decyzje podejmowane przez osoby $z$ niepełnosprawnością intelektualną będą prawidłowe, z drugiej zaś strony często uważają, że za podjęte decyzje osoby te nie potrafią wziąć pełnej odpowiedzialności. Często wybierają opcje decydowania we wszystkich sprawach życiowych za osoby niepełnosprawne intelektualne. Konsekwencją tego jest uzależnienie od otoczenia osób z niższym potencjałem intelektualnym, które z czasem przekształca się w wyuczoną bezradność (Pilecka 2012, s. 21). Ponieważ dla osób, które mają podjąć zatrudnienie, wyuczona bezradność będzie przeszkodą $\mathrm{w}$ realizacji zadań pracownika, konieczne jest położenie nacisku na rozwój umiejętności podejmowania decyzji i odpowiedzialności. Dzięki temu nie dozna ona porażek w pracy zawodowej.

Rozwój umiejętności budowania własnego systemu wartości i kierowania sobą to kolejne zadanie stojące przed rodzicami i terapeutami osoby z niepełnosprawnością intelektualną. T. Żółkowska (2009) wskazuje, że system wartości i ich hierarchia odzwierciedlają kulturę społeczeństwa, aktualne warunki społeczne, ekonomiczne oraz kontakty społeczne, które człowiek nawiązuje. Normy społeczne i wzory zachowań $\mathrm{w}$ danym społeczeństwie są jednym z podstawowych czynników kształtowania wartości. Wartością staje się dla człowieka to, co jest potrzebne do jego życia, komfortu fizycznego i psychicznego, rozwoju aktywności, poczucia bycia potrzebnym i szczęśliwym. Badania prowadzone przez wspomnianą autorkę w populacji osób z niepełnosprawnością intelektualną wskazują, że badani podkreślają znaczenie rodziny pochodzenia i dążenie do założenia własnej. Duże 
znaczenie przypisują takim wartościom, jak miłość i przyjaźń oraz wskazują na potrzebę posiadania własnego miejsca pobytu. Podkreślają też znaczenie pracy jako istotnego czynnika zapewniającego możliwość samodzielnego życia i podejmowania ważnych ról społecznych. Świat wartości osoby z niepełnosprawnością intelektualną wpływa też na podejmowane przez nią decyzje. Sztuka przygotowania do podejmowania własnych wyborów i ponoszenie konsekwencji własnych decyzji to ważny element rehabilitacji osób z głębszą niepełnosprawnością intelektualną.

Stosunkowo niskie umiejętności radzenia sobie ze stresem przez osoby z niepełnosprawnością intelektualną (Wolska 2015) wskazują na konieczność ich rozwoju $\mathrm{w}$ rodzinie $\mathrm{i} w$ placówkach edukacyjnych oraz terapeutycznych. Osoby $\mathrm{z}$ niepełnosprawnością intelektualną podejmujące pracę w nowym środowisku, wśród nowych ludzi, w nowych sytuacjach społecznych często nie radzą sobie z poziomem lęku, który im towarzyszy. Źródłem stresu w pracy mogą być zadania, odbierane jako przekraczające możliwości pracownika, konflikty ról, niepewność zatrudnienia i zagrożenie bezrobociem, zbyt duże tempo pracy, brak przerw, praca $\mathrm{w}$ warunkach presji czasu i przeciążenia stymulacją, odpowiedzialność za trudne decyzje, objawy niezadowolenia ze strony przełożonych i wiele innych czynników. Osoby z wysokim poziomem lęku odbierają stresory ze znacznie większą siłą z powodu obniżonego progu odporności. Szczególnie silnie reagują na stres w sytuacji braku poparcia społecznego, poczuciu zagrożenia, w nowych, nieznanych warunkach.

Umiejętności zarabiania na życie kształtowane są od pierwszych lat życia dziecka. Jeśli rodzice podkreślają mocno te zadania i aktywności, które dziecko z niepełnosprawnością intelektualną wykonało dobrze i nagradzają jego drobne sukcesy, stwarzają okazję do podejmowania obowiązków domowych, to kształtują w nim odpowiedzialność i umiejętność współpracy. Te umiejętności będą bardzo przydatne w podjęciu pracy zawodowej w dorosłym życiu. Dziecko dostaje od bliskich pozytywne informacje zwrotne, gdy wykona zadanie prawidłowo oraz konstruktywną krytykę. Gdy coś wymaga korekty - to uczy się niezależności i myślenia krytycznego, w tym świadomości, czym jest dobrze wykonana praca. Poza przyswajaniem konkretnych umiejętności w rodzinie dziecko ma możliwość obserwacji innych członków rodziny podczas pracy, rozmawiania z sąsiadami, znajomymi, rodzicami o pracy, którą wykonują - dzięki temu kształtuje się w dziecku wyobrażenie o zawodach.

Przygotowując osobę z niepełnosprawnością intelektualną do podjęcia pracy trzeba pamiętać, iż możliwości zawodowe osób głębiej upośledzonych umysłowo są zdecydowanie mniejsze niż w przypadku osób lekko upośledzonych. Otrębski (2007, s. 104-105) wskazuje, że osoby niepełnosprawne mogą się nauczyć wykonywania wielu prostych czynności, które są przydatne w różnych pracach. Trud- 
ności, które im towarzyszą, najczęściej związane są z zachowaniem się w sytuacji pracy i przystosowaniem się do jej wymagań. Dotyczy to zwłaszcza: punktualności, zdyscyplinowania, systematyczności, dokładności wykonania zadania, utrzymania porządku na stanowisku pracy. Czynnikami w sposób widoczny wspomagającymi ich przystosowanie się do warunków pracy są: wyraźne, zrozumiałe i osiągalne postawienie celu oraz stwarzanie zachęt do pracy. Jeśli ograniczenia w osoby są większe, wtedy potrzebuje ona dłużej trwającego usprawniania, aby móc adekwatnie zachowywać się w sytuacji pracy. Im bardziej przyjazne i otwarte jest środowisko rehabilitacji i zatrudnienia, tym łatwiej osobie utrzymać miejsce pracy.

\section{Zatrudnienie wspomagane szansą dla osób z głębszą niepełnosprawnością intelektualną}

Przygotowanie do podjęcia pracy przez osoby z głębszą niepełnosprawnością intelektualną ma szczególne znaczenie w ostatnich latach, kiedy to jest realna możliwość podjęcia przez nie zatrudnienia na otwartym rynku pracy. Dzięki projektom zatrudnienia wspomaganego realizowanym $\mathrm{w}$ naszym kraju osoby z głębszą niepełnosprawnością intelektualną uczą się trudnej sztuki bycia pracownikiem. Nie jest to łatwe zadanie, gdyż trzeba wypełniać zadania zawodowe, przyjąć obowiązki i egzekwować prawa wynikające z roli zawodowej, współpracować z zespołem pracowników lub co najmniej być przez nich tolerowanym tak organizować życie, by godzić obowiązki z całokształtem zadań życiowych (Karney 2007, s. 313). Znalezienie przez osoby niepełnosprawne odpowiedniej dla siebie pracy wiąże się z wieloma trudnościami. Trudności, szczególnie na etapie uzyskania pracy i adaptacji pracowników niepełnosprawnych w zakładzie pracy, legły u podstaw koncepcji zatrudnienia wspomaganego. W tej koncepcji przygotowania do pracy przez „wspomaganie” rozumie się szeroki zakres różnorodnych usług pomagających i wspierających aktywność zawodową osoby niepełnosprawnej, czyli uzyskanie przez nią możliwie najwyższego poziomu umiejętności zawodowych i stosownego zatrudnienia (Majewski 2011, s. 15). W formie tej niepełnosprawny pracownik jest wspierany w pracy przez trenera pracy, który pomaga mu zaadaptować się w pracy i wykonywać zadania zawodowe. $\mathrm{W}$ miarę rozwoju pracownika pomoc asystenta ulega stopniowemu zmniejszeniu, aż do całkowitego wycofania się. Długość okresu wsparcia jest ustalana indywidualnie w zależności od potrzeb pracownika i pracodawcy. Forma ta znajduje zastosowanie w przypadku osób ze znacznymi niepełnosprawnościami, szczególnie z głębszą niepełnosprawnością intelektualną. 
Chrześcijańskie Stowarzyszenie Osób Niepełnosprawnych ich Rodzin i Przyjaciól "Ognisko" od 2005 roku realizuje projekty mające na celu jak najpełniejsze przygotowanie osób dorosłych z głębszą niepełnosprawnością intelektualną do podjęcia zatrudnienia. Obecnie na otwartym rynku pracy aktywnych zawodowo jest ponad 360 beneficjentów. W projektach uczestniczyło o wiele więcej osób, lecz nie wszystkim udało się utrzymać podjętą pracę. Część beneficjentów uznała, że nie jest gotowa do jej podjęcia i pozostała w dziennych ośrodkach wsparcia (WTZ, ŚDS). Niekiedy rodziny, bojąc się porażki lub utraty świadczeń, nie wyrażały zgody na zatrudnienie osoby z niepełnosprawnością.

Jednym z warunków zatrudnienia i utrzymania pracy przez osoby z głębszą niepełnosprawnością intelektualną był wysoki poziom umiejętności życiowych. Dlatego umiejętności te badanych osób z niepełnosprawnością intelektualną, uczestników projektów zatrudniania wspomaganego wyznaczyły dalszy kierunek procesu badawczego. W celu przeprowadzenia badań wykorzystałam Skale Umiejętności Życiowych - SUŻ (Wolska 2015, s. 267). Składa się ona z 6 podskal złożonych z 5-8 itemów pozwalających ocenić poziom umiejętności życiowych osób z niepełnosprawnością intelektualną w zakresie umiejętności interpersonalnych związanych z komunikowaniem, umiejętności podejmowania decyzji i odpowiedzialności, umiejętności z zakresu samoobsługi, umiejętności budowania własnego systemu wartości i kierowania sobą, umiejętności radzenia sobie ze stresem i umiejętności zarabiania na życie. Osoba wypełniająca ankietę - rodzic, trener pracy, pracownik socjalny, terapeuta zajęciowy czy inna osoba znająca umiejętności beneficjenta proszona była o ustosunkowanie się na 4-stopniowej skali do treści przedstawionych itemów. W prezentowanych badaniach, za pomocą modelowania strukturalnego wykazałam zależności pomiędzy podejmowaniem i nie podejmowaniem aktywności zawodowej przez osoby z niepełnosprawnością intelektualną, po zakończeniu udziału w projekcie zatrudnienia wspomaganego a ich umiejętnościami życiowymi.

\section{Umiejętności życiowe a aktywizacja zawodowa beneficjentów $\mathrm{z}$ perspektywy modelowania strukturalnego}

Aby uzyskać dane potrzebne do tworzenia modelu strukturalnego zbadano poziom umiejętności życiowych 200 osób z niepełnosprawnością intelektualną, które brały udział w projektach zatrudnienia wspomaganego: 100 beneficjentów, którzy podjęli pracę po zakończeniu udziału w projekcie oraz 100 osób, które nie podjęły zatrudnienia, gdy projekt dobiegł końca. 
Modelowanie strukturalne służy do analizy struktury oraz siły liniowych zależności pomiędzy badanymi zjawiskami. Umożliwia ono analizę zależności przyczynowo-skutkowych - tak jak regresja, ale także zależności korelacyjnych. Model to zestaw równań regresji i korekcji pomiędzy zmiennymi, najczęściej przedstawiony za pomocą schematu graficznego. Na podstawie struktury zależności oraz parametrów opisujących ich siłę - np. korelacji i współczynników regresji można wyprowadzić teoretyczną postać macierzy wariancji - kowariancji zmiennych użytych w modelu (Badyńska, Książek 2013, s. 62). Artykuł prezentuje modele przy pomocy wykresu ścieżkowego. Zmienne obserwowalne przedstawiono jako prostokąty, nieobserwowalne - jako elipsy. W modelach zmiennych obserwowalnych elipsami zaznaczono jedynie składniki losowe. Zależność przyczynowo-skutkową ukazano przy pomocy strzałki skierowanej od zmiennej niezależnej w danej relacji. Łuk obustronnie zakończony strzałką odpowiada kowariancji i wskazuje na zależność pomiędzy dwiema zmiennymi, która nie ma charakteru przyczynowo-skutkowego. Każdy z elementów jest lub może być powiązany $\mathrm{z}$ parametrami modelu. Każda strzałka odpowiada jednemu współczynnikowi ścieżkowemu. Parametr ten opisuje kierunek i siłę relacji przyczynowo-skutkowej. Współczynnikami ścieżkowymi są współczynniki regresji B. Parametrem powiązanym łukiem zakończonym strzałkami $\mathrm{z}$ obu stron jest współczynnik kowariancji. Dla zmiennych, które wyłącznie objaśniają w modelu inne zmienne, ale same nie są przez inne zmienne objaśniane oszacowano wariancje. Elementy składowe modeli strukturalnych stanowią zmienne jawne i ukryte (latentne). Na zmienne jawne składają się informacje liczbowe, które zostały uzyskane $\mathrm{w}$ procesie badawczym. Zmienne latentne to konteksty, w których zachodzą sytuacje modelowe (por. StatSoft, Inc. 2005, STATISTICA, data analisis system).

Interpretacji $\mathrm{w}$ modelu regresji wielokrotnej podlegają niestandaryzowane i standaryzowane współczynniki regresji nazywane współczynnikami ścieżkowymi. Niestandaryzowane współczynniki ścieżkowe informują, o ile jednostek zmieni się wartość zmiennej objaśnianej, gdy wartość danej zmiennej objaśniającej wzrośnie o 1 jednostkę. Współczynniki standaryzowane opisują, o ile swoich odchyleń standardowych zmieni się wartość zmiennej objaśnianej, gdy wartość zmiennej objaśniającej wzrośnie o jedno jej odchylenie standardowe (Badyńska, Książek 2013, s. 167).

Ponieważ podstawą do konstruowania modeli strukturalnych umiejętności życiowych beneficjentów biorących udział w projekcie zatrudnienia wspomaganego jest wiedza teoretyczna zdobyta na podstawie analizy literatury oraz wyniki wcześniej przeprowadzonych analiz statystycznych dotyczących tego tematu modelowanie rozpoczęłam od modelu zawierającego 6 wariancji, czyli takiego, który uwzględnia wszystkie powiązania strukturalne pomiędzy zmiennymi. 
Przystępując do analizy zebranego materiału badawczego nie wiemy jakie współzależności występują pomiędzy poszczególnymi umiejętnościami życiowymi, dlatego założyłam wstępnie, że istnieją współzależności pomiędzy wszystkimi elementami i zweryfikowałam model. Wyniki badań zawarłam w publikacji z 2015 roku. Obecnie zaprezentuję modele, które powstały po wydzieleniu z modelu 6 wariancyjnego trzech umiejętności życiowych, które najsilniej wpływały na zależności pomiędzy poszczególnymi zmiennymi. Po opuszczeniu mało znaczących połączeń powstały modele 3 wariancyjne.

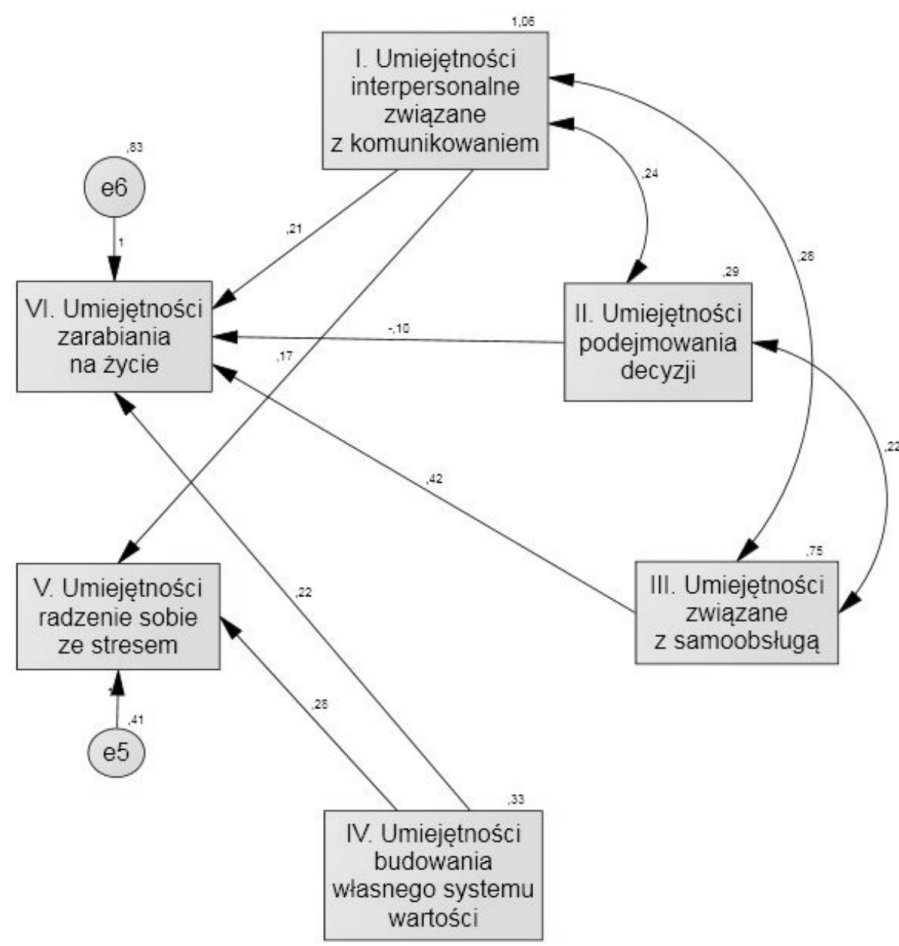

Ryc. 1. Model niestandaryzowanych współczynników ścieżkowych dla grupy I - beneficjentów, którzy podjęli zatrudnienie

Wyżej umieszczona rycina przedstawia model niestandaryzowanych współczynników ścieżkowych modelu uwzględniającego 3 wariancje pomiędzy umiejętnościami życiowymi osób z niepełnosprawnością intelektualną, które pracują na otwartym rynku pracy po zakończeniu udziału w projekcie zatrudnienia wspomaganego. $\mathrm{W}$ przypadku wyższych o jeden umiejętności związanych $z$ samoobstuga, umiejętności zarabiania na życie są wyższe o 0,42. Jeśli umiejętności budowania własnego systemu wartości są wyższe o jeden przekłada się to na umiejętności radzenia sobie ze stresem o 0,28 stopnia i na umiejętności zarabiania na życie wyższe o 0,22. 
Natomiast jeśli umiejętności interpersonalne związane z komunikowaniem się są wyższe o jeden to umiejętności zarabiania na życie są wyższe o 0,21. Wzrost umiejętności podejmowania decyzji w badanej grupie beneficjentów nie wpływa na umiejętności zarabiania na życie $(-0,01)$.

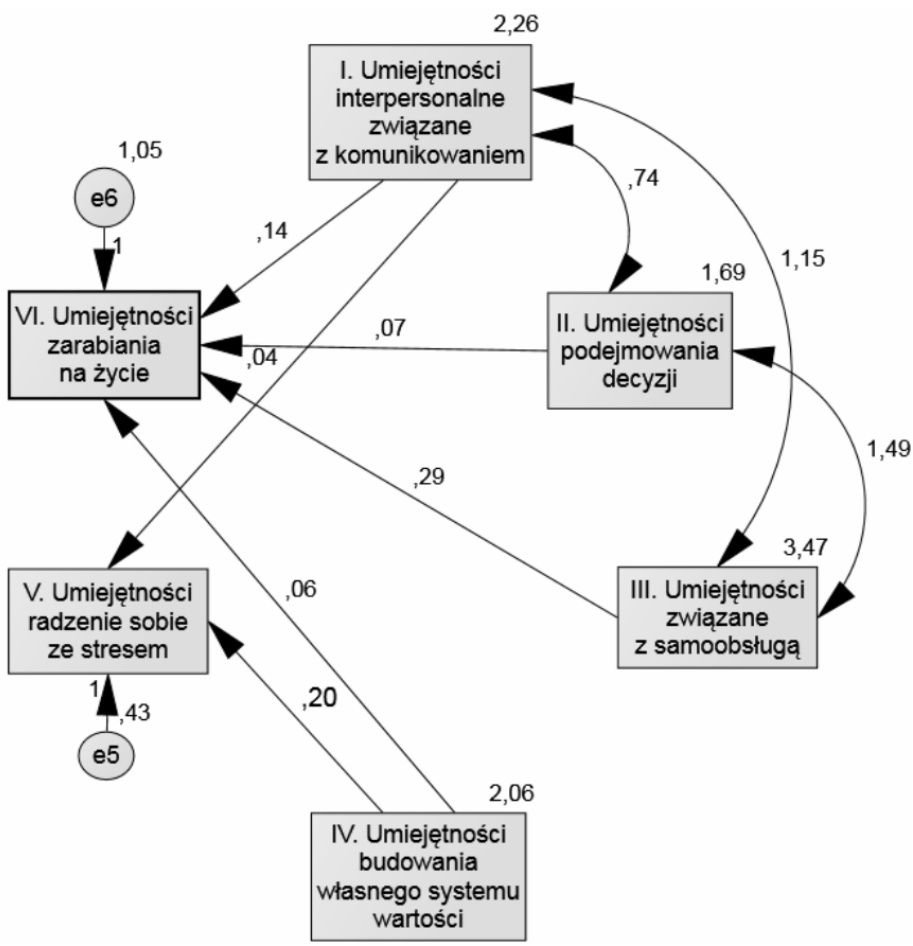

Ryc. 2. Model niestandaryzowanych współczynników ścieżkowych dla grupy II - beneficjentów, którzy nie podjęli zatrudnienia

Model niestandaryzowanych współczynników ścieżkowych dotyczący umiejętności życiowych osób z niepełnosprawnością intelektualną, które nie podjęły pracy po zakończeniu udziału w projekcie zatrudnienia wspomaganego przedstawia rycina 2 . Zgodnie $\mathrm{z}$ uzyskanymi oszacowaniami ocena umiejętności życiowych związanych z samoobstugq wyższa o jeden stopień na odpowiadającej im skali przekłada się na umiejętności zarabiania na życie wyższe o 0,30 na przyporządkowanej im skali. Wzrost o jeden stopień umiejętności budowania własnego systemu wartości powoduje wzrost o 0,20 stopni umiejętności radzenia sobie ze stresem. W przypad$\mathrm{ku}$ wyższych o jeden umiejętności interpersonalnych związanych z komunikowaniem, umiejętności zarabiania na życie są wyższe o 0,13.

$\mathrm{Na}$ podstawie wartości współczynników niestandaryzowanych można stwierdzić, iż ich nasilenie w grupie beneficjentów, którzy po zakończeniu 
udziału $\mathrm{w}$ projekcie zatrudnienia wspomaganego nie podjęli pracy jest słabsze niż w grupie beneficjentów pracujących.

Zestawienie powyższych zależności wskazuje, że w badanej populacji osób z niepełnosprawnością intelektualną różnice pomiędzy grupami dotyczą następujących zależności: grupa osób pracujących różni się od grupy niepracujących ścieżką między umiejętnościami budowania wtasnego systemu wartości i umiejętnościq zarabiania na życie. Można założyć, że praca sama w sobie stanowi wartość dla badanych beneficjentów, którzy są aktywni zawodowo i to wpływało na wzrost motywacji do jej podjęcia po zakończeniu udziału w projekcie zatrudnienia wspomaganego. W grupie osób, które nie pracują po zakończeniu udziału w projektach różnice dotyczą umiejętności związanych z samoobstugą i umiejętności zarabiania na życie. To potwierdza konieczność rozwijania potencjału związanego z samoobsługą w biegu całego życia beneficjentów, aby mógł być on wykorzystany $\mathrm{w}$ okresie podejmowania przez nich aktywności zawodowej w dorosłym życiu.

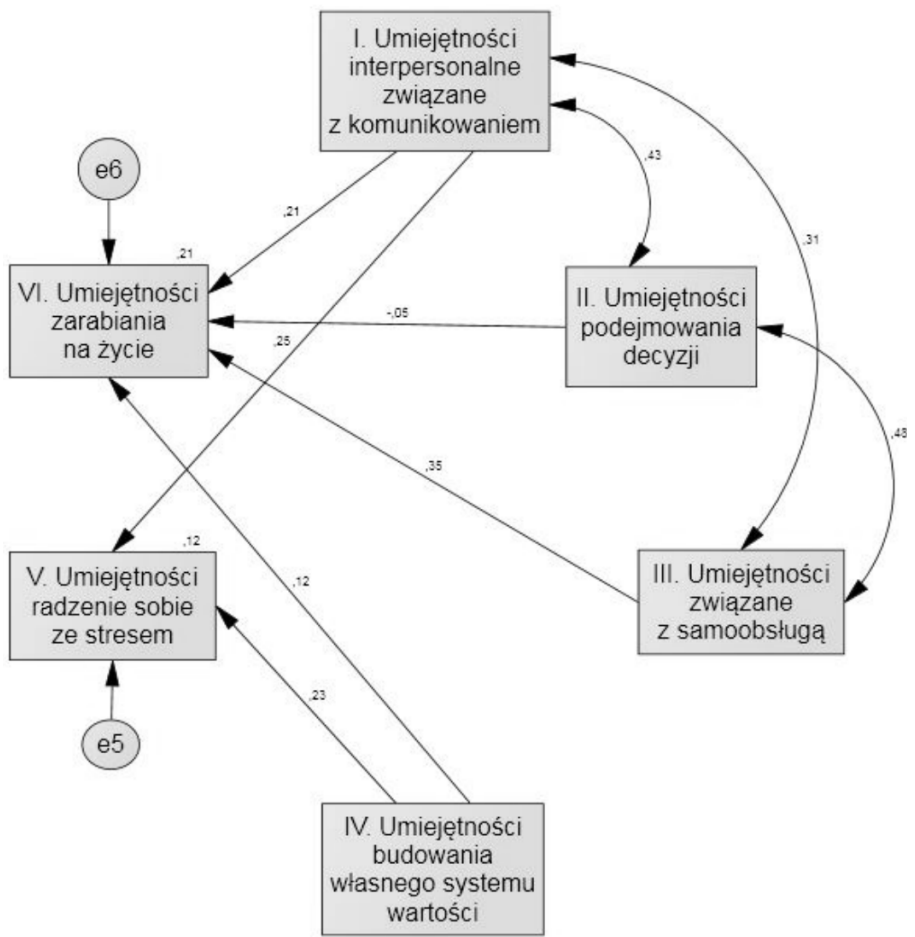

Ryc. 3. Standaryzowany model umiejętności życiowych grupy I - beneficjentów, którzy podjęli zatrudnienie

Interpretacja standaryzowanych współczynników przedstawionego wyżej modelu przedstawia się następująco: Jeżeli umiejętności budowania własnego syste- 
mu wartości są wyższe o jedno odchylenie standardowe to umiejętności zarabiania na życie są wyższe o 0,35 swojego odchylenia standardowego. Umiejętności interpersonalne zwiqzane $z$ komunikowaniem wyższe o jedno odchylenie standardowe pociągają za sobą wyższy o 0,26 odchylenia standardowego poziom umiejętności radzenia sobie ze stresem. Wyższe o jedno odchylenie standardowe umiejętności budowania własnego systemu wartości oznaczają wyższe o 0,23 umiejętności radzenia sobie ze stresem. Umiejętności interpersonalne zwiazane z komunikowaniem wyższe o jedno odchylenie standardowe to wyższe o 0,21 odchylenia standardowego umiejętności życiowe zwiqzane z zarabianiem na życie. Wyższa o jedno odchylenie standardowe umiejętność budowania własnego systemu wartości daje wyższe o 0,12 odchylenie standardowe umiejętności zarabiania na życie.

Parametr przy zmiennej życiowej dotyczącej umiejętności podejmowania decyzji przez osoby z niepełnosprawnością intelektualną i ich wpływ na umiejętności zarabiania na życie nie podlega interpretacji, ponieważ jest statystycznie nieistotny $(-0,052)$.

Na podstawie wartości współczynników standaryzowanych można stwierdzić, że najważniejszą determinantą umiejętności życiowych osób z niepełnosprawnością intelektualną związaną z umiejętnościami zarabiania na życie są umiejętności związane $z$ samoobstuga. Prawie o połowę mniejsze znaczenie mają umiejętności interpersonalne zwiazane z komunikowaniem, a jeszcze mniej istotne są umiejętności budowania własnego systemu wartości. Poziom umiejętności podejmowania decyzji nie ma istotnego wpływu na umiejętności zarabiania na życie w grupie osób z niepełnosprawnością intelektualną, które podjęły pracę po zakończeniu udziału w projek- cie zatrudnienia wspomaganego.

Natomiast determinantą umiejętności życiowych w zakresie radzenia sobie ze stresem $\mathrm{w}$ prezentowanej grupie badawczej są umiejętności interpersonalne zwiąane $z$ komunikowaniem i umiejętności budowania własnego systemu wartości.

Analiza standaryzowanego modelu umiejętności życiowych osób z niepełnosprawnością intelektualną, które nie podjęły zatrudnienia po zakończeniu udziału $\mathrm{w}$ projekcie pozwala stwierdzić, że jeżeli umiejętności zwiqzane z samoobstuga są wyższe o jedno odchylenie standardowe to umiejętności zarabiania na życie są wyższe o 0,30 swojego odchylenia standardowego. Umiejętności budowania własnego systemu wartości pociągają za sobą wyższy o 0,20 odchylenia standardowego poziom umiejętności radzenia sobie ze stresem. Wyższe o jedno odchylenie standardowe umiejętności interpersonalne zwiazzane z komunikowaniem się wpływają na wyższe o 0,14 odchylenia standardowego umiejętności zarabiania na życie. Wartości współczynników standardowych pozwalają stwierdzić, że najważniejszą determinantą umiejętności życiowych w grupie osób, które nie podjęły zatrudnienia, związaną z umiejętnościami zarabiania na życie są umiejętności związane z samoobstuga. Zdecydowanie mniejsze znaczenie mają umiejętności interpersonalne 
zwiazane z komunikowaniem się a jeszcze mniej istotne są umiejętności podejmowania decyzji i umiejętności budowania własnego systemu wartości. Determinantą umiejętności życiowych $\mathrm{w}$ zakresie radzenia sobie ze stresem $\mathrm{w}$ prezentowanej grupie badawczej są umiejętności budowania własnego systemu wartości i umiejętności interpersonalne związane z komunikowaniem.

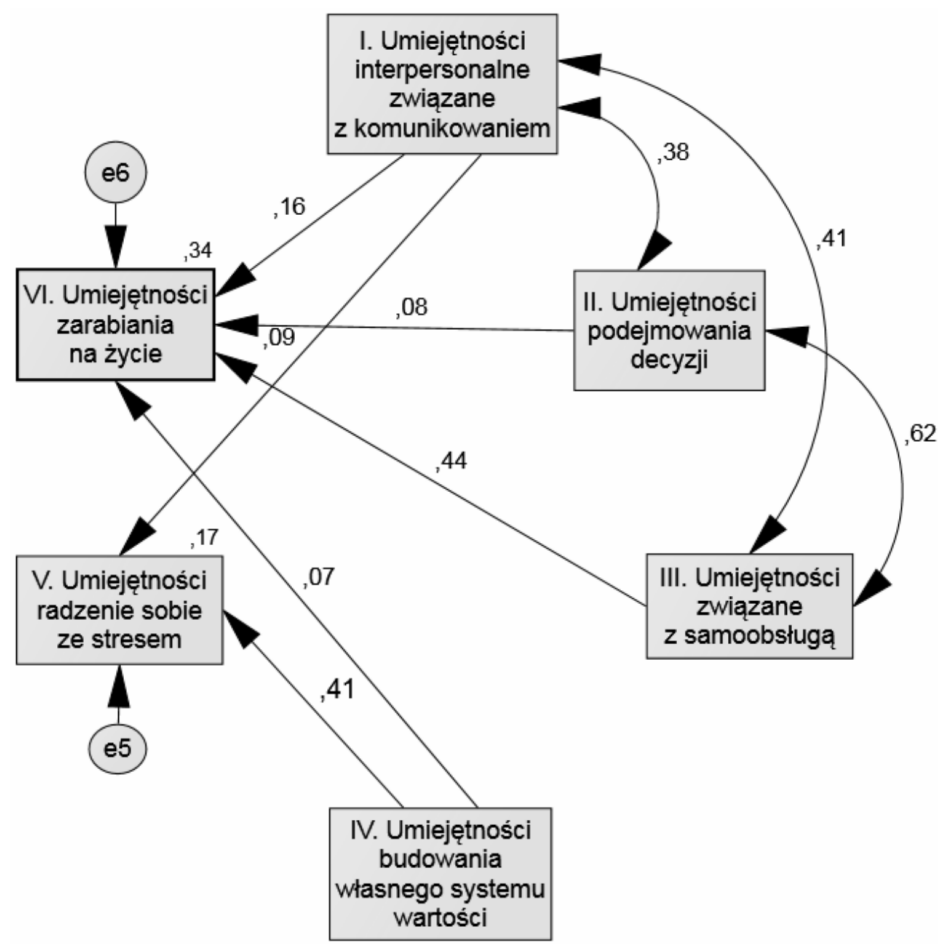

Ryc.4. Model standaryzowanych współczynników ścieżkowych dla grupy II - beneficjentów, którzy nie podjęli zatrudnienia

Być może badana grupa osób z głębszą niepełnosprawnością intelektualną po zakończeniu udziału w projekcie zatrudnienia wspomaganego uznała, że nie posiadają wystarczającego do podjęcia pracy poziomu umiejętności z zakresu samoobsługi i komunikowania. A może taka była sugestia rodziców, opiekunów lub terapeutów? Istnieje konieczność kontynuowania badań w tym zakresie, gdyż procent osób, które po zakończeniu udziału w projektach podejmują zatrudnienie jest wciąż nie wysoki. 


\section{Zakończenie}

Porównując rezultaty przedstawionego modelowania strukturalnego można stwierdzić, że wzajemne powiązania wyróżnionych umiejętności życiowych beneficjentów pracujących i niepracujących po zakończeniu udziału w projektach charakteryzują się różnym nasileniem. Największe różnice zachodzą pomiędzy umiejętnościami związanymi z samoobstuga, które są wyraźnie silniejsze w grupie osób pracujących, natomiast w grupie niepracujących pozostają w słabych zależnościach. Przygotowując osobę z głębszą niepełnosprawnością intelektualną do podjęcia pracy szczególny nacisk trzeba położyć na rozwój jej umiejętności życiowych z zakresu samodzielności, komunikowania i budowania własnego systemu wartości. Aby podjąć i utrzymać zatrudnienie osoba niepełnosprawna powinna dobrze radzić sobie w sytuacjach stresowych. W obydwu badanych grupach umiejętności radzenia sobie ze stresem są związane z umiejętnościami interpersonalnymi związanymi z komunikowaniem i umiejętnościami budowania własnego systemu wartości.

Analiza modelowa daje podstawę do ewentualnych modyfikacji programów aktywizacji zawodowej w kierunku nie tylko zwiększania poszczególnych umiejętności życiowych, ale uaktywnienia współzależności pomiędzy tymi umiejętnościami. Podczas prowadzonej aktywizacji zawodowej osób dorosłych z niepełnosprawnością intelektualną należy nie tylko kłaść nacisk na rozwój umiejętności życiowych, ale także uwzględnić konwersje tych umiejętności. Przeprowadzone badania własne wyraźnie wskazują, że wykształcenie jednej umiejętności życiowej na wysokim poziomie powoduje, że inne umiejętności zostają wzmocnione.

\section{Bibliografia}

Bedyńska S., Książek M. (2012), Statystyczny drogowskaz 3. Praktyczny poradnik wykorzystania modeli regresji oraz równań strukturalnych, Wydawnictwo Akademickie Sedno, Warszawa.

Błeszyński J. (2013), Niepetnosprawność intelektualna. Mowa, język, komunikacja. Czy iloraz inteligencji wyjaśnia wszystko?, Harmonia Uniwersalis, Gdańsk.

Giermanowska E. (2007), Młodzi Niepetnosprawni-aktywizacja zawodowa i nietypowe formy zatrudnienia, Fundacja Instytut Spraw Publicznych, Warszawa.

Karasiewicz K., Makarowski R. (2012), Modelowanie strukturalne z programem AMOS - wybrane modele równań strukturalnych na przykładach z psychologii, SWPS SPSS POLSKA, Warszawa.

Karney J. E. (2007), Psychopedagogika pracy. Wybrane zagadnienia z psychologii i pedagogiki pracy, Wydawnictwo Akademickie "Żak”, Warszawa.

Majewski T. (2011), Poradnictwo zawodowe i pośrednictwo pracy dla osób niepetnosprawnych. Poradnik dla urzędów pracy, Biuro Pełnomocnika Rządu ds. Osób Niepełnosprawnych, Warszawa.

Maksymowicz L. (2009), Umiejętności życiowe osób przewlekle chorych i niepetnosprawnych jako warunek osiagania sukcesu i podnoszenia jakości życia [w:] Osoba z niepetnosprawnościa-opie- 
ka, terapia, wsparcie, red. J. Baczała, J. Błeszyński, M. Zaorska, Wydawnictwo Naukowe UMK, Torun.

Otrębski W. (2007), Interakcyjny model rehabilitacji zawodowej osób z upośledzeniem umysłowym, Wydawnictwo KUL, Lublin.

Pilecka W. (2012), Psychoruchowy rozwój dzieci o obniżonej sprawności umysłowej, [w:] Stymulacja psychoruchowego rozwoju dzieci o obniżonej sprawności umysłowej, red. W. i J. Pileccy, Wydawnictwo Naukowe UP, Kraków.

Woynarowska B. (2002), Kształtowanie umiejętności życiowych u dzieci i młodzieży - wyzwanie dla szkoty, "Chowanna”, t. 1, nr 18.

Woynarowska B. (2007), Edukacja zdrowotna. Podręcznik akademicki, Wydawnictwo Naukowe PWN, Warszawa.

Wolska D. (2015), Umiejętności życiowe jako wyznacznik aktywizacji zawodowej dorostych z głębsza niepetnosprawnością intelektualna, Wydawnictwo Naukowe Uniwersytetu Pedagogicznego, Kraków. 